INTERNATIONAL MONETARY FUND

\title{
Greece's Investment \\ Gap
}

Shiqing Hua, María Méndez, and Xin Cindy Xu

WP/22/13

2022

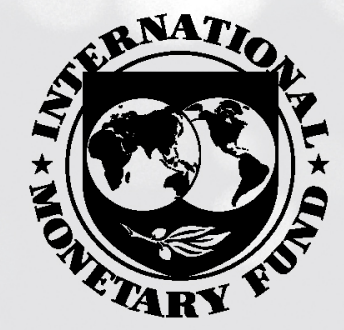


IMF Working Paper

European Department

\title{
Greece's Investment Gap'
}

\author{
$\mathrm{WP} / 22 / 13$ \\ Shiqing Hua, María Méndez, and Xin Cindy Xu \\ Authorized for Distribution by Dennis Botman
}

IMF Working Papers describe research in progress by the author(s) and are published to elicit comments and to encourage debate. The views expressed in IMF Working Papers are those of the author(s) and do not necessarily represent the views of the IMF, its Executive Board, or IMF management.

\begin{abstract}
Greece's investment rate plunged following the Sovereign Debt Crisis (SDC) and remained one of the lowest in the world in 2019. This paper explores recent investment dynamics and compares them against estimated benchmarks. Our results suggest that Greece has been under-investing since the SDC, with private investment notably lagging behind. The estimated investment gap ranges from 1.6-8 percent of GDP in 2019. Structural impediments have constrained corporate investment, while business cycle and balance sheet developments have held back household investment. Structural reforms are recommended to remove bottlenecks to corporate investment, improve efficiency of public investment, and boost household investment.
\end{abstract}

\begin{tabular}{|l|l|}
\hline JEL Classification Numbers: & E22;H54;O16 \\
\hline Keywords: & Investment gap, capital stock, structural reforms \\
\hline Author's E-Mail Address: & shua@imf.org;mmendez@imf.org;xxu2@imf.org; \\
\hline
\end{tabular}

${ }^{1}$ Ritzy Dumo and Daniel Murphy Pineda provided assistance. The paper benefitted from comments from Dimitris Malliaropulos, Marianthi Anastasatou, and Filippos Petroulakis (all BoG) and the Greek Council of Economic Advisers. 


\section{Table of Contents}

Abstract

A. Background

B. Capital Stocks and Investment: Where Does Greece Stand? $\underline{5}$

C. Is Greece Under-investing? What is the size of the Investment Gap?

D. Sectoral Drives of Investment

E. Conclusion and Policy Recommendations

Figures

1. Capital Stock and Output $\underline{6}$

2. Selected Infrastructure $\underline{7}$

3. Investment Rate $\underline{8}$

4. Investment by Industry $\underline{9}$

5. Investment by Economic Sector $\underline{10}$

6. Benchmark Investment Rates and Investment Gap 12

7. Determinants of the Investment Gap $\underline{13}$

8. Other Drivers of Low Business Investment $\underline{16}$

9. Drivers of Household Investment $\underline{18}$

10. Transport, ICT, \& Health Infrastructure Gap $\underline{21}$

\section{Tables}

1. Estimating Benchmark Investment Rates: Three Analytical Approaches $\underline{11}$

2. Investment Gap Estimates under different Model Specifications $\underline{14}$ Appendix

I. Investment Gap Estimations 23 


\section{A. Background}

To raise potential growth and living standards, Greece needs stronger capital accumulation and productivity. Higher investment and productivity are particularly relevant for an aging society, where a shrinking population is expected to weigh heavily on potential output (text figure). IMF staff's baseline projects that the real investment rate stabilizes between 15-17 percent of GDP over the medium term (from 11.6 percent at end-2020), in line with the historical capitaloutput ratio (see text charts). The Greek Government's baseline in the 2021 Stability and Growth Pact envisages the investment-GDP ratio to reach around 17 percent by 2025 , driven by the combination of funding and reforms under the ambitious Recovery and Resilience National Plan (RRP). Both estimates are lower than Greece's presovereign debt crisis peak investment rate of 24 percent of GDP, which contributed, however, to an unsustainable current account deficit.

The decade following the sovereign debt crisis (SDC) featured disappointing investment rates. Following the Eurozone accession in 2001, Greece's investment increased across all sectors, with a notable rise in household investment. However, in the aftermath of the SDC, even as macroeconomic conditions stabilized, investment growth remained subdued, averaging about 0 percent during the period of 2015-19 and resulting in an investment-to-GDP ratio of 10 percent at end-2019. This is close to 10 percentage points lower than the regional average. Investment has started to recover more recently, posting consecutive quarterly growth since 2020Q2, driven by EU funds. Greece also ranks low compared to income peers in terms of the capital stock per capita, contributing to low levels of productivity (Figure 1).

\section{Ample analytical work has sought to identify reasons behind Greece's low investment.}

For example, Gourinchas, Phillipon and Vayanos (2017) suggest that investment in Greece between 2009 and 2013 was impacted by the increase in funding costs due to the sudden stop, but thereafter private-sector credit risk, fiscal austerity, and price-markup shocks have been more relevant drivers. Alogoskoufis (2021) finds lower real interest rates and post-accession euphoria led to a large increase in household investment and a decline in national savings. Meanwhile, business investment 
was constrained by structural characteristics and incomplete reforms in a context of fiscal and internal adjustment. Albani, Papageorgiu, and Sideris (2018) identify uncertainty and financial conditions as the main determinants of subdued business investment in the post-crisis years.

There are few studies on Greece's investment gap. Most literature uses historical averages and peer group comparisons as investment benchmarks for Greece. However, historical investment includes the unsustainable pre-crisis boom and peer group comparisons would not capture Greece's economic fundamentals and structural characteristics. Recent IMF work has explored various analytical approaches to estimate investment gaps in other European countries. For example, the IMF Regional Economic Outlook for Europe (May 2016) explores the "golden-rule" investment rate- - a theoretic steady-state rate based on the neo-classical growth model, and the "historical benchmark"-an empirical approach based on historical dynamics of advanced European countries, to estimate investment gaps for emerging market European countries. The IMF selected issue paper for Poland (2017) develops a "predicted norm" investment benchmark that is determined by countries' own economic fundamentals and structural characteristics. These analytical approaches will be explored to study Greece's investment benchmark. Specifically, the next section provides stylized facts on investment and the capital stock. The third section presents three approaches to estimate Greece's investment gap. The fourth section identifies constraints to investment by sector. We conclude with policy implications.

\section{B. Capital Stock and Investment: Where Does Greece Stand?}

\section{Greece's total capital stock is broadly in line with the regional average, but private} capital lags behind (Figure 1). The total capital stock to GDP ratio is close to the euro area's average, while the net capital stock per capita in Greece is about two thirds of the Euro Area's average. Greece's net capital stock contracted by an average of 1.2 percent annually in the last decade. However, this was relatively less than the decline in output (22 percent cumulatively). As elsewhere in the region, most of the capital stock is held by the private sector (70 percent of total) and this is where the widest gap exists compared to peers. However, at end-2019 the total net capital stock stood broadly in line with the regional average thanks to the higher-than-average public capital stock, the third largest in the region in percent of GDP. The relative importance of public capital and the low level of the private stock is reflected in the rising public-to-private capital ratio, estimated close 
to 45 percent in 2019 and higher than the growth-maximizing ratio found in the literature for advanced economies (42 percent). ${ }^{2}$ This could potentially have growth implications, as discussed in Section D.

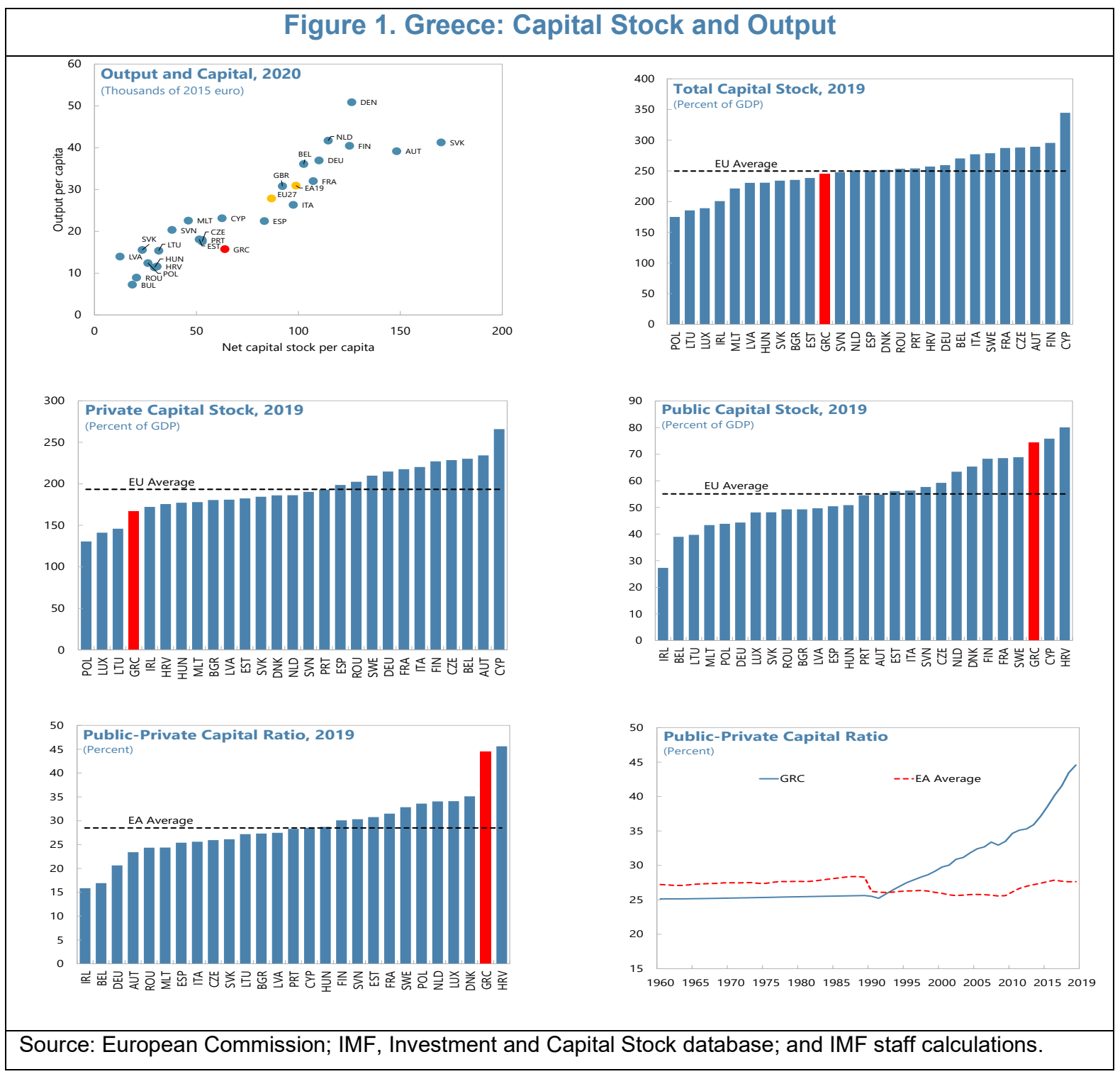

The picture in infrastructure is mixed, with sizeable gaps in transportation and to a lesser extent in energy, digital, and healthcare infrastructure (Figures 2, 10). Greece's transportation infrastructure is lower than the EU average, with nearly 30 percent lower road density and 60 percent lower railroad density compared to peers, though this is partly due to Greece's

${ }^{2}$ EIB (2005). In addition, Kangur et al (2019) find evidence of complementarity (not substitutability) of public and private capital stocks, particularly for advanced economies. Kangur et al also find public-private ratios tend to average 30 percent for Advanced Economies (15 percent lower than Greece's) which could indicate suboptimality of Greek asset ownership. 
geography (islands and rugged mountain terrain) and the gap has likely narrowed in recent years given completion of several motorways. Greece is closer to the EU average in utility infrastructure, notably in electricity generation capacity and renewable energy production. While water supply reliability ranks high, water transport has gaps. ${ }^{3}$ Information and communication technology (ICT) infrastructure in Greece are slightly higher than regional peers, except for mobile phone penetration (7 percent below EU average). Greece has higher-than-average medical devices and equipment, but as of 2019 the number of hospital beds was 16 percent below the EU (this may have improved in the context of COVID-19). As of 2018, the health security index in Greece was also lower than the regional average, though this likely improved given health infrastructure investments during the pandemic.

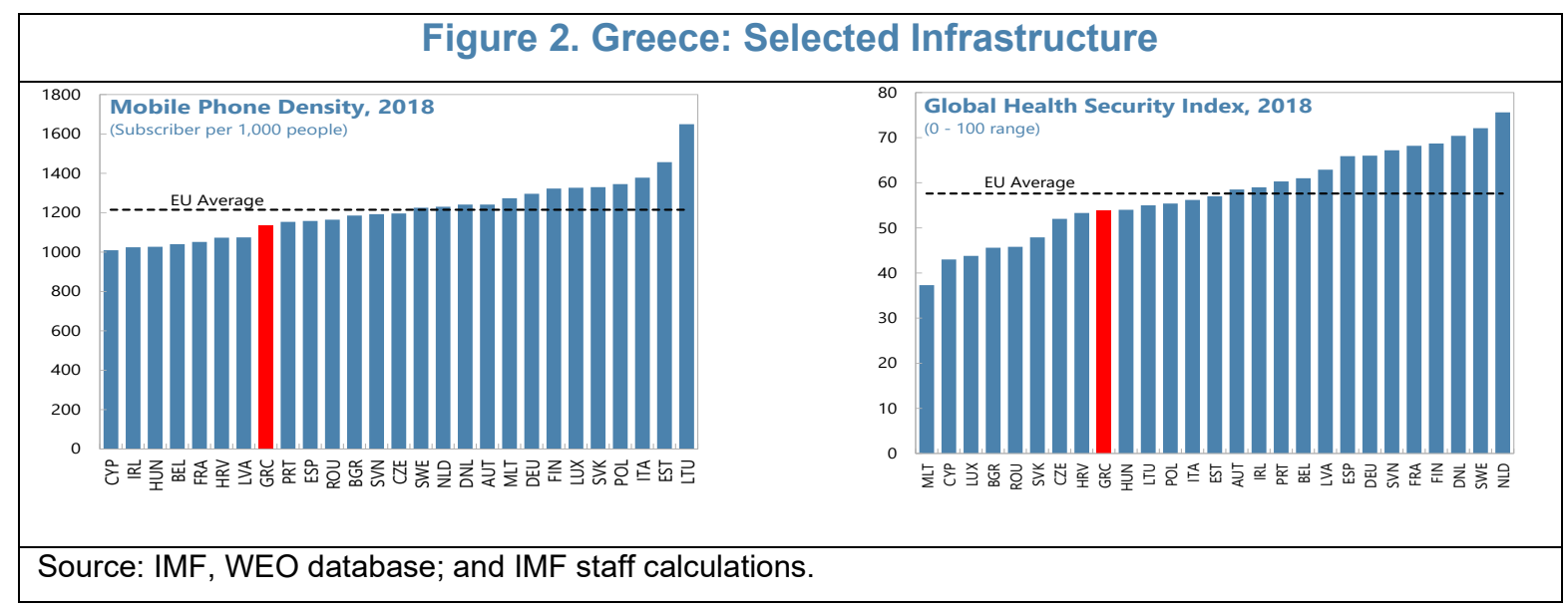

At end -2019 Greece's investment rate was one of the lowest in the world (Figure 3).

Prior to 2008, Greece's investment rate was broadly in line with peers (Cyprus, Portugal, and Spain) and close to or above the EU average.

Investment was particularly strong in the construction sector, notably in residential dwellings. After dropping sharply at the onset of the GFC (2008-10), the investment-to-GDP ratio has remained flat on an annual basis, with large volatile swings between quarters subject to purchases of ships or arms/equipment (text chart). By end-2019, Greece's investment-to-

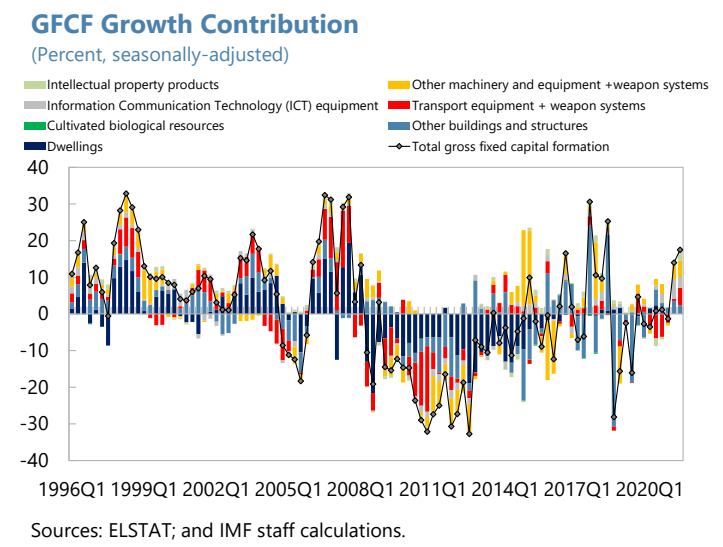

\footnotetext{
${ }^{3}$ Global Competitiveness Report (2019) ranks Greece 61 out of 100 countries in Water Transport and 91 out of a 100 countries in Water Supply Availability.
} 
GDP ratio ranked the lowest in the EU and among the lowest in the world, at 10 percent of GDP. ${ }^{4}$

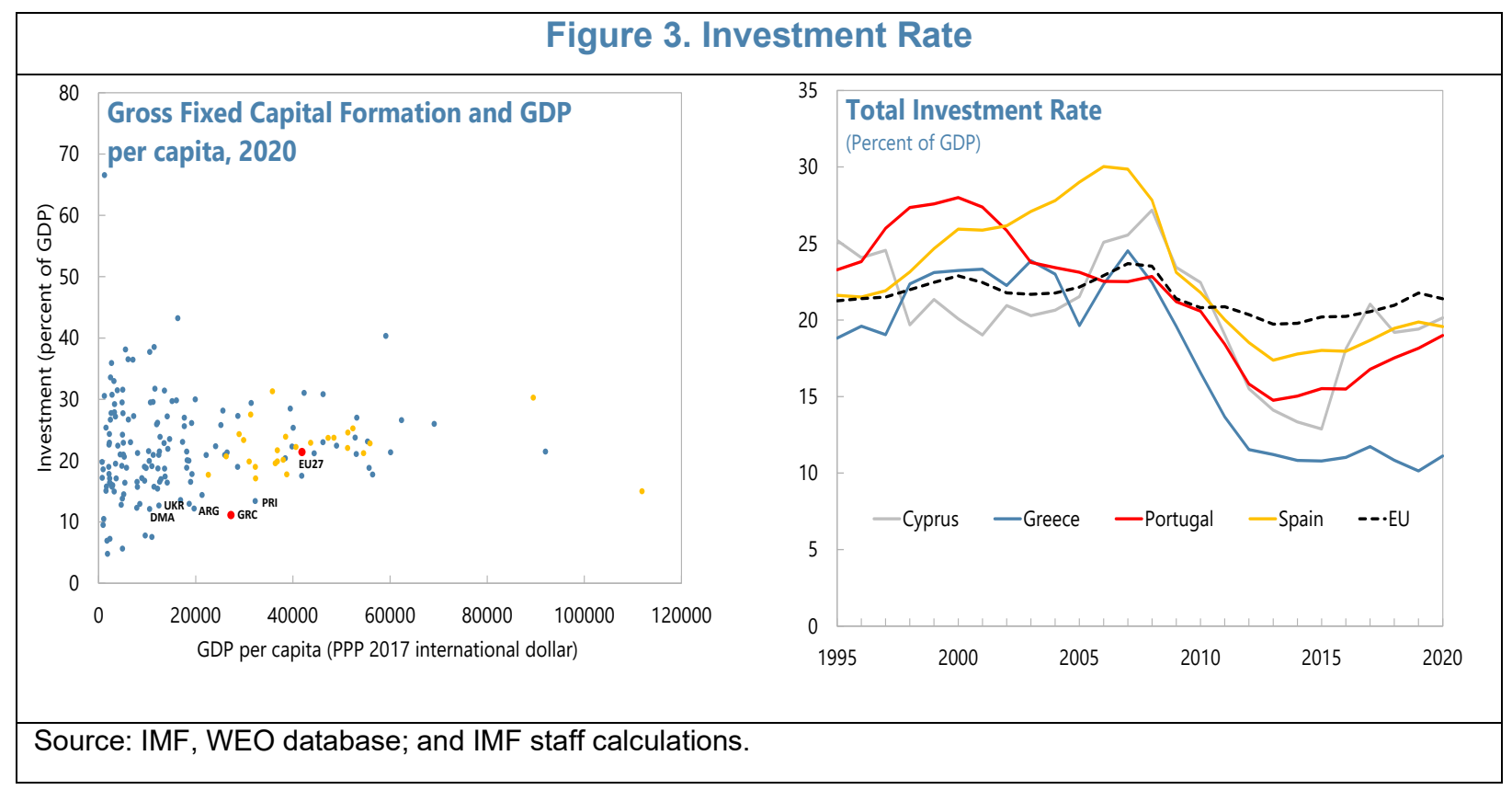

\section{Low investment is prevalent across industries, particularly in real estate, followed by} manufacturing and other industries. From an industry perspective, the drop in investment has been largely driven by the housing market slump. Historically, Greek investment centered around the real estate industry and service sectors, while primary and secondary industries were relatively under-invested in (see Figure 4). At its peak, the real estate industry represented 40 percent of total investment and nearly 10 percent of GDP. As the housing market collapsed in 2007, the country suffered one of the steepest reductions in housing prices across the EU. The introduction of higher property taxes and the contraction in household disposable incomes sharply lowered investment in real estate. From 2007 to 2019, investment in dwellings and other building structures dropped by more than 80 percent, and total investment in the real estate industry currently represents less than 1 percent of GDP, significantly below the level of its regional peers and the EU average of 4.5 percent of GDP.

\footnotetext{
${ }^{4}$ According to ELSTAT's provisional 2020 national accounts published on October 2021, gross fixed capital formation (GFCF) contracted by -0.7 during 2020 and stood at 11 percent of GDP. GFCF (SA) growth rates through 2021:H1 suggested a strong rebound (11.8 percent y-t-d growth rate) for 2021 . These figures are likely to be revised in in subsequent releases, including due to updated data that would become available as restrictions linked to pandemic are removed. For this reason, this paper works on the basis of figures as of end2019.
} 


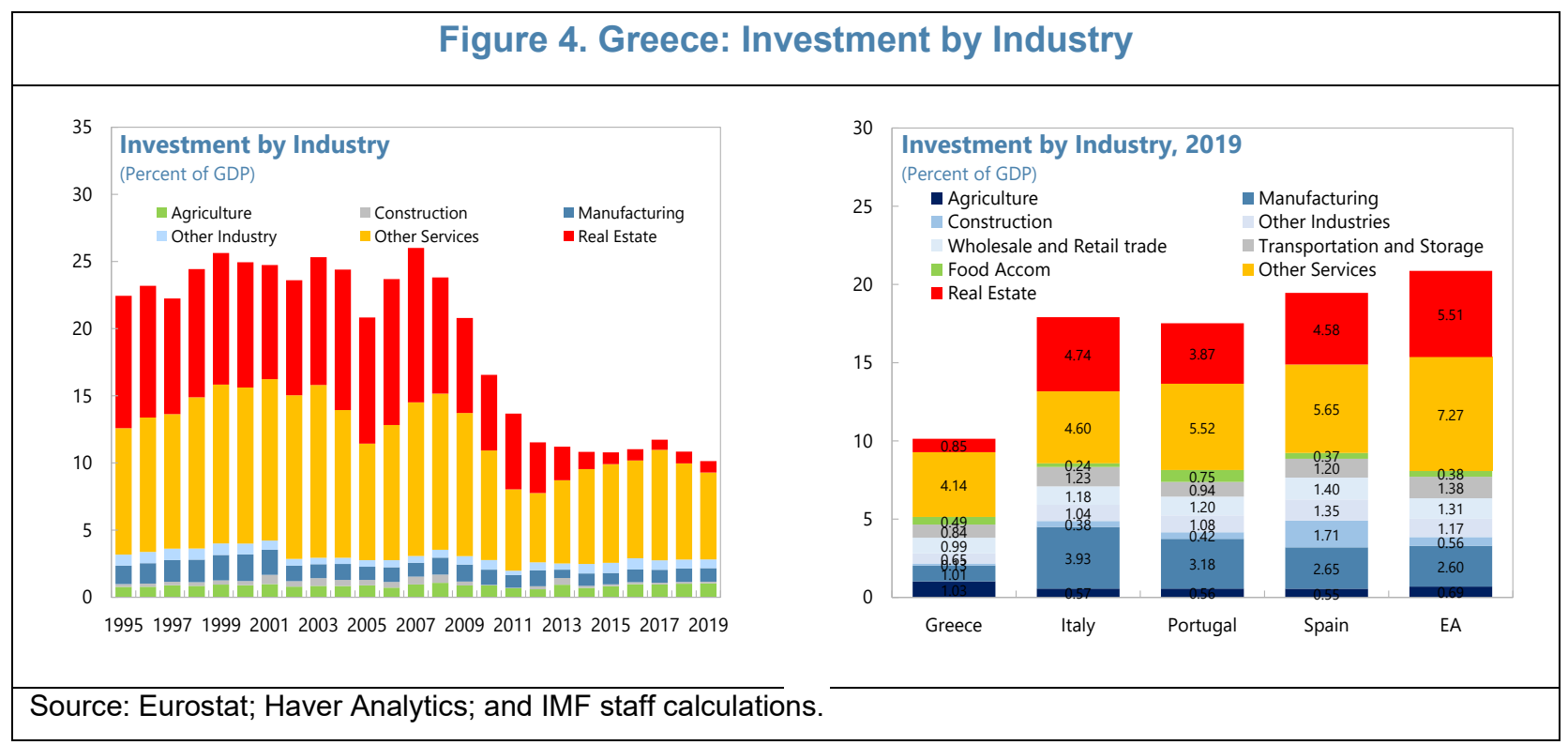

Household investment has retrenched the most since the sovereign debt crisis, but it is in business investment where the highest regional gap is found (Figure 4). Low investment is broad-based across the private sector. Greece currently ranks at the bottom among EU countries in both business and household investment.

- Business investment has the widest gap (about 10 percentage points lower) compared to the EU. Greece has been consistently below the EU average and the gap has increased recently.

- Household investment was once half of total investment in Greece, almost twice the size of the regional average prior to the sovereign debt crisis, but it has since experienced the sharpest drop (over 10 percentage points). The household sector now features the lowest investment rate across three economic sectors.

- Government investment in Greece has been relatively stable and higher than the EU average in relative terms in the past two decades. Boosted by EU funds, public capital expenditure remained around 2 percentage points higher than EU level until 2011 when it briefly dropped below due to spending cuts. However, it quickly rebounded in 2013 before dipping again in 2019. 


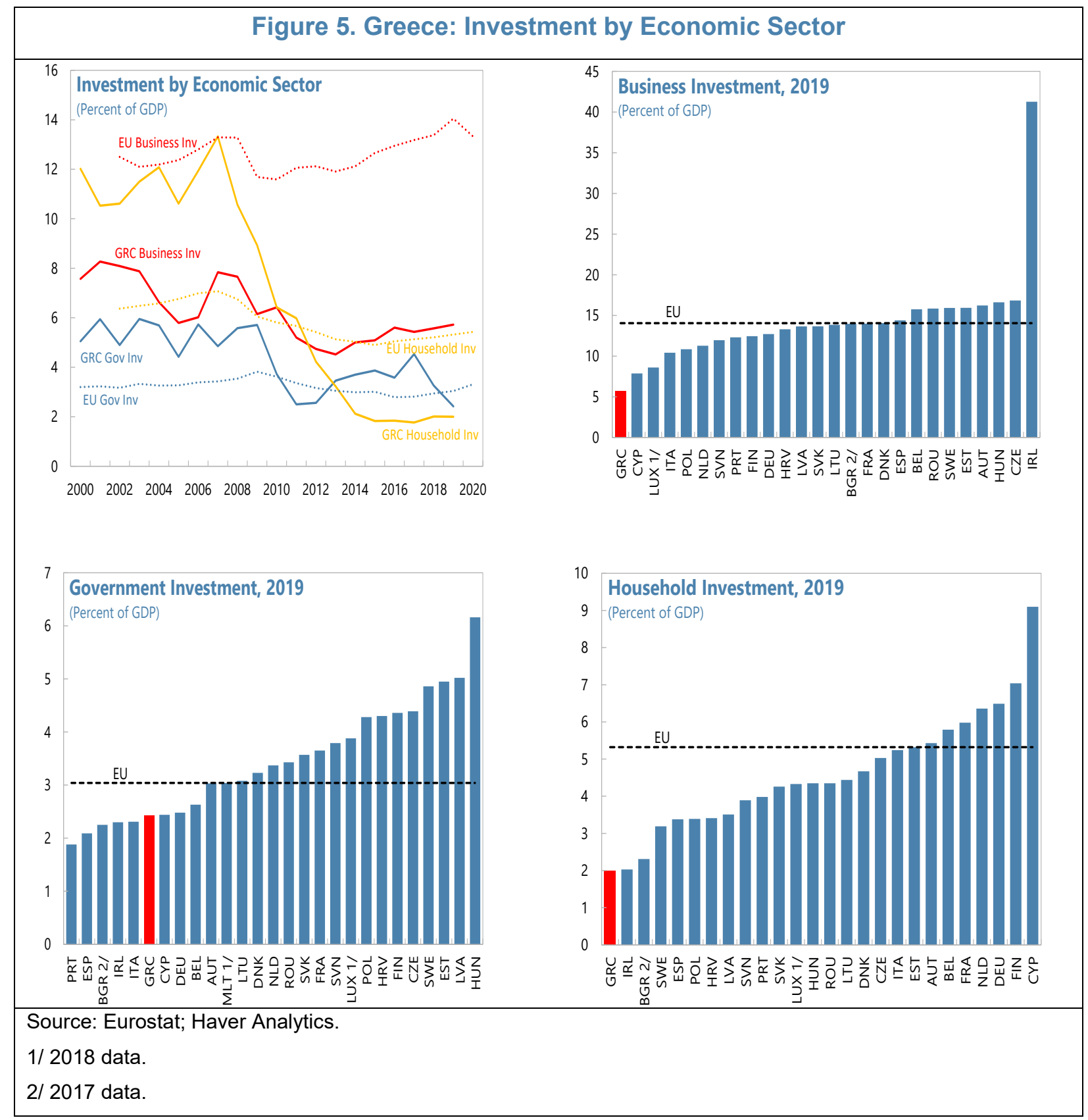

Sectoral investment dynamics must be considered with certain caveats. Given Greece's prevalence of micro family-owned firms, investment by unincorporated enterprises ("self-employed") can often be accounted as household investment, while public capital expenditure can include capital transfers destined for SOE operations. Arms or ship purchases are reflected in highly volatile swings in quarterly investment growth figures, but these may have no bearing on private sector growth. Given the difficulty in weeding out true measures of private sector investment, the analysis in Section $C$ focuses on total investment. We provide more granular analysis by sector in Section D. 


\section{Is Greece under-investing based on alternative methodologies for estimating the Investment Gap?}

Following recent IMF work $(2016,2017)$, this section applies three approaches to estimate Greece's total investment benchmark rates. ${ }^{5}$ These include: (i) the "Golden Rule" approach, a neo-classical growth model-based steady-state equilibrium level of investment; (ii) the "Historical Benchmark", the stylized transition investment dynamics derived from the historical experience of selected advanced European countries (Germany, France, Spain, Italy) who have successfully achieved convergence; and (iii) the "Predicted Norm", the estimated investment rate determined by a set of economic fundamentals and structural characteristics, through a panel regression from a sample of $27 \mathrm{EU}$ countries over the past three decades. Each method has merits and drawbacks (Table 1), but taken together, they provide a good measure of Greece's benchmark investment rates (Annex I).

\begin{tabular}{|l|l|l|}
\hline \multicolumn{2}{|c|}{ Table 1. Estimating Benchmark Investment Rates: Three Analytical Approaches } \\
\hline Methods & Pros & Cons \\
\hline Golden Rule & $\begin{array}{l}\text { A steady-state equilibrium rate, invariant } \\
\text { to initial conditions. }\end{array}$ & $\begin{array}{l}\text { Require knowledge of unobservable } \\
\text { variables (e.g. social rate of time } \\
\text { preference, SRTP). }\end{array}$ \\
\hline $\begin{array}{l}\text { Historical } \\
\text { Benchmark }\end{array}$ & $\begin{array}{l}\text { Proven achievable and sustainable } \\
\text { investment rate based on historical } \\
\text { experience of advanced EU peers. }\end{array}$ & $\begin{array}{l}\text { Assumes a similar economic structure as } \\
\text { advanced EU peers, independent of } \\
\text { external balance consideration. }\end{array}$ \\
\hline $\begin{array}{l}\text { Predicted } \\
\text { Norm }\end{array}$ & $\begin{array}{l}\text { Value determined by set of Greece's own } \\
\text { economic fundamentals, structural } \\
\text { characteristics, and external factors. }\end{array}$ & $\begin{array}{l}\text { Sample and model specification } \\
\text { dependent. }\end{array}$ \\
\hline
\end{tabular}

\section{Greece's current investment rate falls short of the benchmarks across all three methods}

(Figure 6). The size of the estimated investment gap (as of 2019) ranges from 1.6 to 8 percent of GDP depending on the approach and the specification.

i. The "golden rule" approach standard estimate points to an investment gap of about 4 percent of GDP. In its standard form, the golden rule may be interpreted as a steady state to which the investment-to-GDP ratio converges. The assumptions for the future may be based on estimates of reform payoffs that encourage savings (such as pension reform) and/or those that increase the capital share of income (through a decline in the number of self-employed and economies of scale). This approach is suitable for Greece because of the prevalence of selfemployed workers and because of Greece's low level of domestic savings. 6 The standard calculation for the period 2015-19 adjustment-which does not adjust the capital income share and uses the average social rate of time preference-suggests an investment gap of about

${ }^{5}$ See more details in Annex I, the IMF REI (May 2016), and IMF Poland Selected Issues (July 2017)

${ }^{6}$ The unadjusted labor share is calculated in the Penn World Tables as total compensation over GDP. Following IMF (2016), the adjusted the labor by increasing the unadjusted labor share by adding either 100 or 67 percent of the income of the self-employed based on balance sheet data. For savings, we adjust the social rate of time preference upward/downward from the standard average for the Euro Area found in the literature (5 percent). 
4 percent. Adjusting the labor share of income, the savings preferences, or the methodology for calculating total factor productivity (TFP) 7, changes the size of the gap as expected (e.g. higher savings preferences imply a higher steady state to converge to and a higher investment gap compared to the present.

ii. The largest estimated gap at end-2019 (8 percent) arises in the "historical benchmark" approach, but this represents an upper bound. Under this perspective Greece has been under-investing even prior to the sovereign debt crisis, although the benchmark itself has declined relative to its pre-crisis level. This approach may not be suited for Greece as it assumes full convergence to mature economy characteristics, including "balanced growth" that does not compromise external balances. In the past, Greece has approached this historical benchmark, but not sustainably so.

iii. The smallest gap is found in the "predicted norm" approach indicating that Greece's low investment rate is largely explained by its income level, economic fundamentals, and structural characteristics. This is the richest of the three approaches as it is grounded in the economy's structural features. It suggests that actual investment is only slightly below the predicted value based on the historical experiences of EU 27 countries and Greece's countryspecific characteristics. The predicted investment benchmark would be much higher (hence, the investment gap would be larger) if Greece's economic fundamentals and structural characteristics improve to the EU average level.

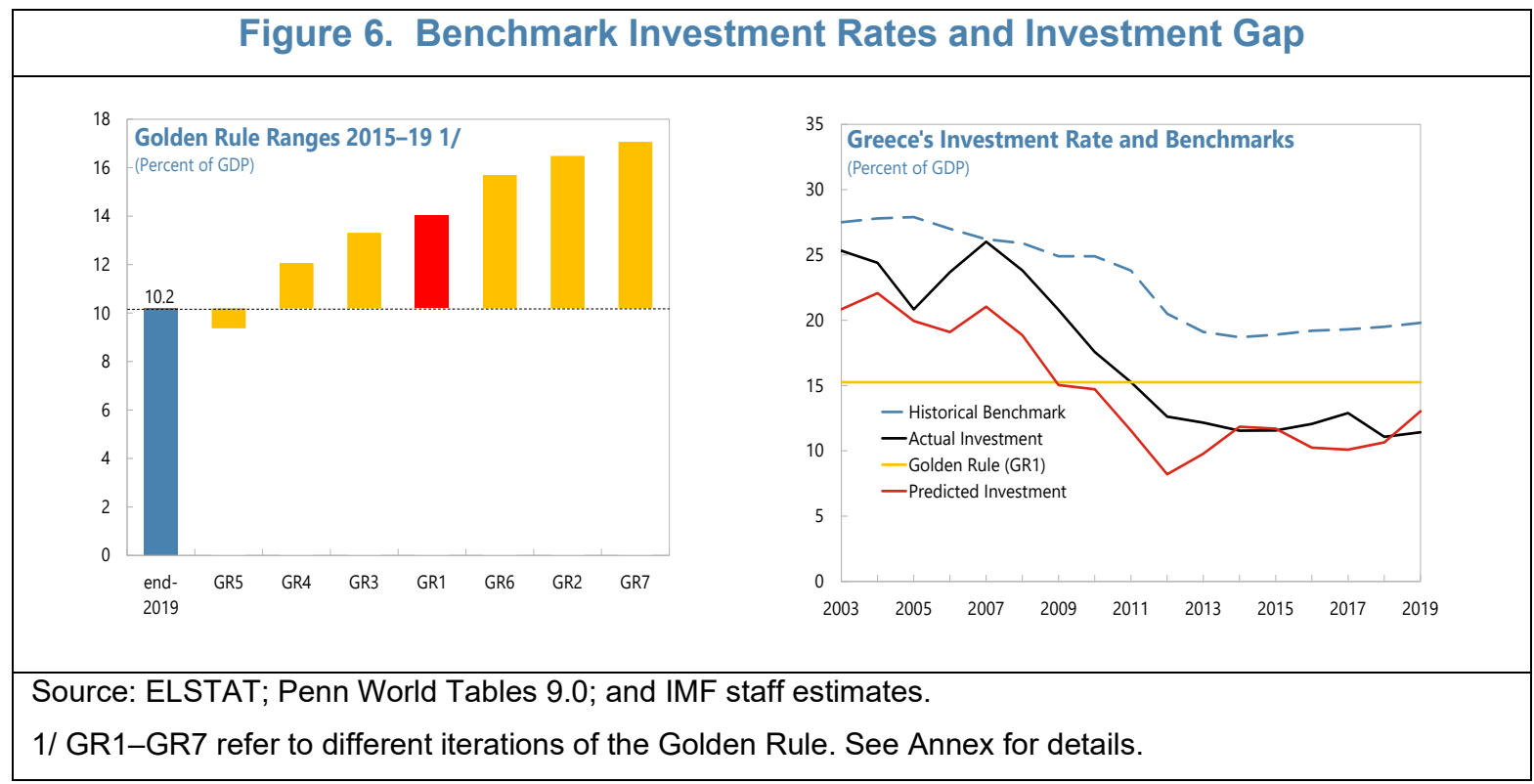

\section{Greece's low investment rate is an outlier compared against its peer group, but it} seems to be in line with its economic structure. The historical benchmark approach suggests that Greece's investment gap has been negative (under-investing) through the period under consideration, echoing Greece's status as an outlier in its investment rates compared to advanced EA peers. The other two, more granular approaches that allow for country-specific characteristics

\footnotetext{
${ }^{7}$ Based on absorption instead of domestic demand, so-called "welfare-maximizing" TFP.
} 
suggest Greece sustained a positive gap (over-investment) prior to the sovereign debt crisis averaging between 4 and 8 percentage points. Since then, Greece has under-invested, but the gap is narrower than its advanced economy status would suggest. At end-2019 the calculated gap ranges between 1.6 (predicted norm) and about 4 percent of GDP (golden rule), broadly in line with the lower bound of staff's baseline investment rate.

The analysis suggests that structural constraints explain the bulk of the investment gap (Figure 7). The golden rule approach shows that the size of the investment gap is sensitive to assumptions about the share of self-employed workers (and how much of their income accrues to labor instead of to capital) and savings preferences. The predicted norm panel regression results show that the size of the investment gap is sensitive to control variables, notably structural factors (Table 2). Absent structural factors, the investment benchmark predicted by Greece's income level and economic fundamentals is close to 20 percent of GDP (mirroring the historical benchmark), with a large gap relative to actual investment at 8 percent of GDP. After adding various structural constraints, the predicted investment rate gets closer to actual levels, with a much smaller gap of 1.6 percent of GDP once all structural factors are controlled for. Looking at the main contributors to the sharp fall in the investment rate from the pre-crisis peak in 2007 to the record-low in 2019, the top three drivers are all structural factors, including the services share, capital account openness (capturing the introduction of capital flow management measures in 2015), and regulatory quality. These three structural factors together account for over 50 percent of the decline. Other control variables, including the income level and economic fundamentals are also statistically significant, but their explanatory power is smaller than structural factors.

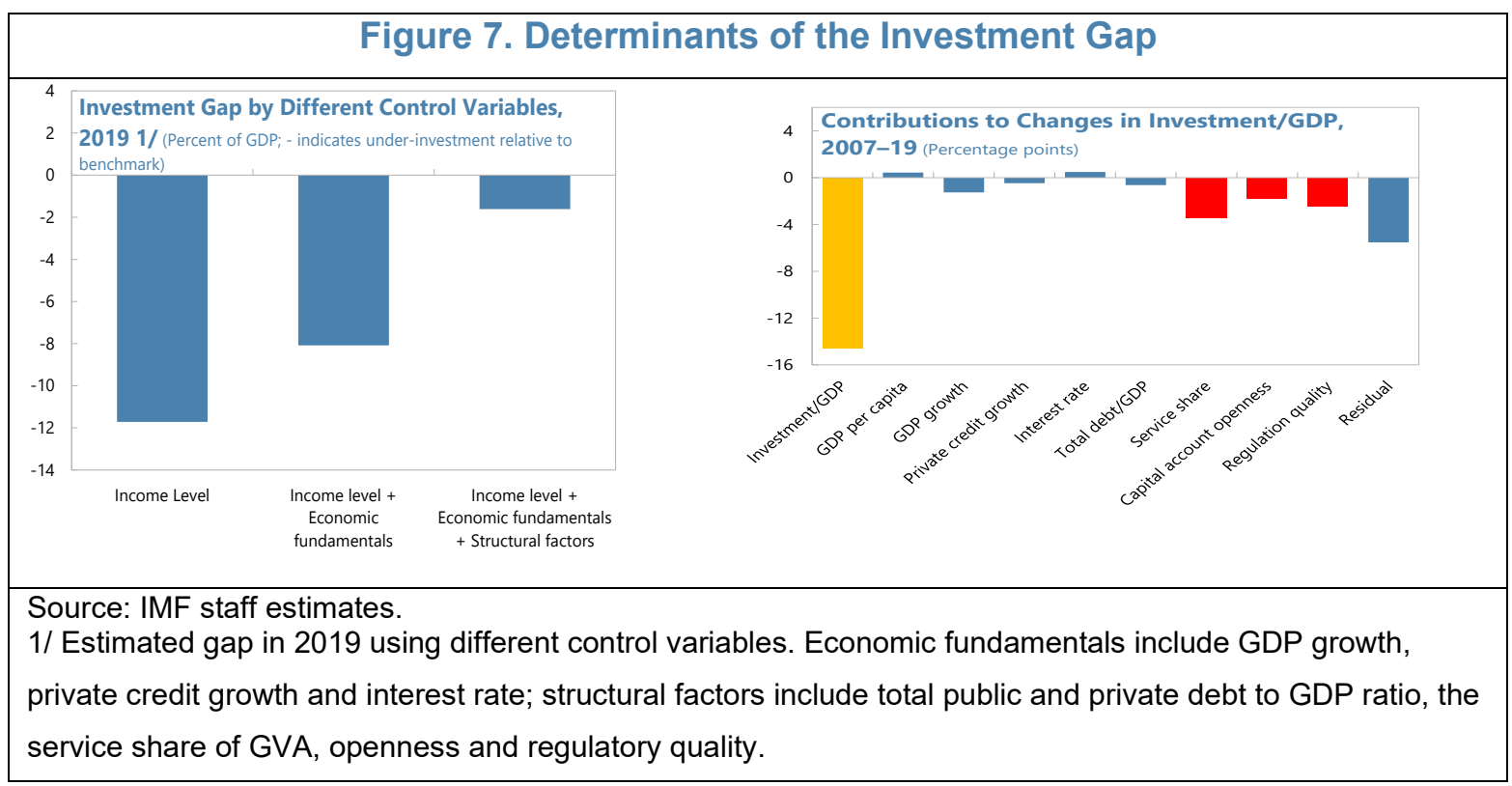




\begin{tabular}{|c|c|c|c|c|c|c|c|}
\hline & (1) & (2) & (3) & (4) & (5) & (6) & (7) \\
\hline VARIABLES & $\mathrm{m} 1$ & m2 & m3 & $\mathrm{m} 4$ & m5 & m6 & $\mathrm{m} 7$ \\
\hline \multirow[t]{2}{*}{ GDP per capita } & $-5.026^{\star * \star}$ & $-2.400^{\star}$ & $4.166^{\star \star}$ & $3.847^{\star *}$ & 2.938 & 0.0176 & $-4.101^{*}$ \\
\hline & $(0.914)$ & $(1.343)$ & $(1.937)$ & $(1.901)$ & $(1.847)$ & $(2.114)$ & $(2.097)$ \\
\hline \multirow[t]{2}{*}{ GDP growth } & $0.405^{\star \star \star}$ & $0.595^{\star \star \star}$ & $0.679^{\star \star \star}$ & $0.627^{\star \star \star}$ & $0.496^{\star \star \star}$ & $0.438^{\star \star *}$ & $0.340^{\star \star \star}$ \\
\hline & $(0.0406)$ & $(0.0470)$ & $(0.0577)$ & $(0.0581)$ & $(0.0620)$ & $(0.0669)$ & $(0.0646)$ \\
\hline \multirow[t]{2}{*}{ Private credit/GDP growth } & & $0.0772^{* * *}$ & ${ }^{\star} 0.0735^{* * *}$ & $0.0605^{* * *}$ & $0.0440^{* * *}$ & $0.0408^{* * *}$ & $0.0337^{* *}$ \\
\hline & & $(0.0139)$ & $(0.0138)$ & $(0.0137)$ & $(0.0137)$ & $(0.0143)$ & $(0.0142)$ \\
\hline \multirow[t]{2}{*}{ Short-term deposit rate } & & & 0.0373 & 0.0770 & 0.0389 & 0.00682 & $-0.232^{\star *}$ \\
\hline & & & $(0.0829)$ & $(0.0828)$ & $(0.0805)$ & $(0.0808)$ & $(0.0945)$ \\
\hline \multirow[t]{2}{*}{ Debt/GDP (public + private) } & & & & $-0.0259 * \star \star$ & $*-0.0208^{* * *}$ & $*-0.0133^{* *}$ & -0.00596 \\
\hline & & & & $(0.00520)$ & $(0.00513)$ & $(0.00552)$ & $(0.00534)$ \\
\hline \multirow[t]{2}{*}{ Service/Gross value added } & & & & & $-0.343^{\star \star \star}$ & $-0.458^{\star \star \star}$ & $-0.512^{\star \star \star}$ \\
\hline & & & & & $(0.0688)$ & $(0.0787)$ & $(0.0745)$ \\
\hline \multirow[t]{2}{*}{ Capital account openness } & & & & & & $0.0349^{\star *}$ & $0.0282^{*}$ \\
\hline & & & & & & $(0.0150)$ & $(0.0146)$ \\
\hline \multirow[t]{2}{*}{ Regulatory quality } & & & & & & & $5.427^{\star \star \star}$ \\
\hline & & & & & & & $(0.864)$ \\
\hline \multirow[t]{2}{*}{ Constant } & $71.16^{\star \star \star}$ & $47.05^{\star \star \star}$ & -18.74 & -17.67 & 14.17 & $47.89^{\star *}$ & $91.29^{\star \star \star}$ \\
\hline & $(8.671)$ & $(13.49)$ & $(19.97)$ & $(19.86)$ & $(20.24)$ & $(23.38)$ & $(22.80)$ \\
\hline Country fixed effect & Yes & Yes & Yes & Yes & Yes & Yes & Yes \\
\hline Year fixed effect & Yes & Yes & Yes & Yes & Yes & Yes & Yes \\
\hline Observations & 1,116 & 515 & 422 & 392 & 392 & 374 & 356 \\
\hline R-squared & 0.363 & 0.546 & 0.519 & 0.540 & 0.572 & 0.598 & 0.659 \\
\hline Number of ifscode & 27 & 27 & 22 & 22 & 22 & 21 & 21 \\
\hline Inv. Gap in 2019 & -11.7 & -10.2 & -8.1 & -6.4 & -4.7 & -3.9 & -1.6 \\
\hline \multicolumn{8}{|c|}{$\begin{array}{l}\text { Standard errors in parentheses. The dependent variable is gross fixed capital formation in percent of GDP, and all control variables } \\
\text { are measured in lag values, including 5-year lag for GDPPC and 1-year lag for the rest. }\end{array}$} \\
\hline${ }^{* * *} p<0.01,{ }^{* *} p<0.05,{ }^{*} p<0.1$ & & & & & & & \\
\hline
\end{tabular}

CInternational Monetary Fund. Not for Redistribution 


\section{Sectoral Drivers of Investment}

Business investment is mainly constrained by structural factors. Corporate investment averaged 7 percent of GDP in the decade preceding the GFC and around $5 \frac{1}{2}$ percent of GDP since. The 2020 EIB Survey notes that 71 percent of firms indicate they invested the "right" amount in the past three years, slightly below the 80 percent EU average, while two thirds of firms were operating at or about capacity in 2019. The highest-cited barrier to investment according to the same survey is business regulation, though this recently improved (from 95 percent of firms in 2019 to 86 percent of firms in 2020). Energy costs (70 percent, from 79 percent in 2019) and labor market regulations (71 percent, down from 78 percent in 2019) are other structural factors that firms cite as limiting investment.

Low returns, high debt levels, and financing constraints may also be at play (Figure 5). The results of the 2020 EIB Survey, however, suggest other drivers could also be at play. In particular, 92 percent of firms note uncertainty about the future remains a barrier to investment, while 62 percent of firms note that low domestic demand prevents them from investing more. We consider others factors here in addition:

- Low returns on capital provides less incentives to invest. The gross return on capital of NonFinancial Corporations (NFCs) in Greece experienced a sharp drop from the pre-crisis peak of 34 percent in 2008 and 38 percent in 2011 to a historic low of 13.7 percent in 2019, 10 percentage points below the EA average.

- High debt burden restrains the companies from investing. The average net debt-to-income ratio of Greek NFCs increased since 2013. By 2016, it had more than doubled compared to its 2008 level. 8 Despite the gradual reduction in the last three years, Greece companies still feature the second highest gross debt burden for the EA-15 region (Figure 8).

- Insufficient domestic savings - together with poor channeling of these as credit-limit the financial resources for corporate investment. In addition, the saving rate of Greek NFCs was lower than the EU average pre-crisis and the gap has widened in recent years. In 2018, the NFC saving-to-GDP ratio dipped into single-digit percentage points for the first time.

\footnotetext{
8 The data sample is different from the Parodi et al (2021 SIP), which is using gross debt/EBITDA firm-level data accounting for 45 percent of total operating revenues of Greek NFCs, mostly excluding small firms. The Eurostat definition uses total debt (sum of currency \& deposits, debt securities, and loans)/(net entrepreneurial income tax).
} 
- Meanwhile, access to bank credit was significantly reduced. The pre-crisis credit boom vanished since the GFC, with negative credit growth until 2020. Banks to date remain in the process of deleveraging their balance sheets, with high though fast declining non-performing exposures (NPEs) still constraining credit supply. According to the EIB Survey, firms in Greece remained considerably more likely to lack access to finance (13 percent) than the EU average (6 percent). Firms also remark on the high cost of finance (12 percent compared to an average of 5 percent in the EU) and on collateral rules (10 percent) as a barrier to investment.

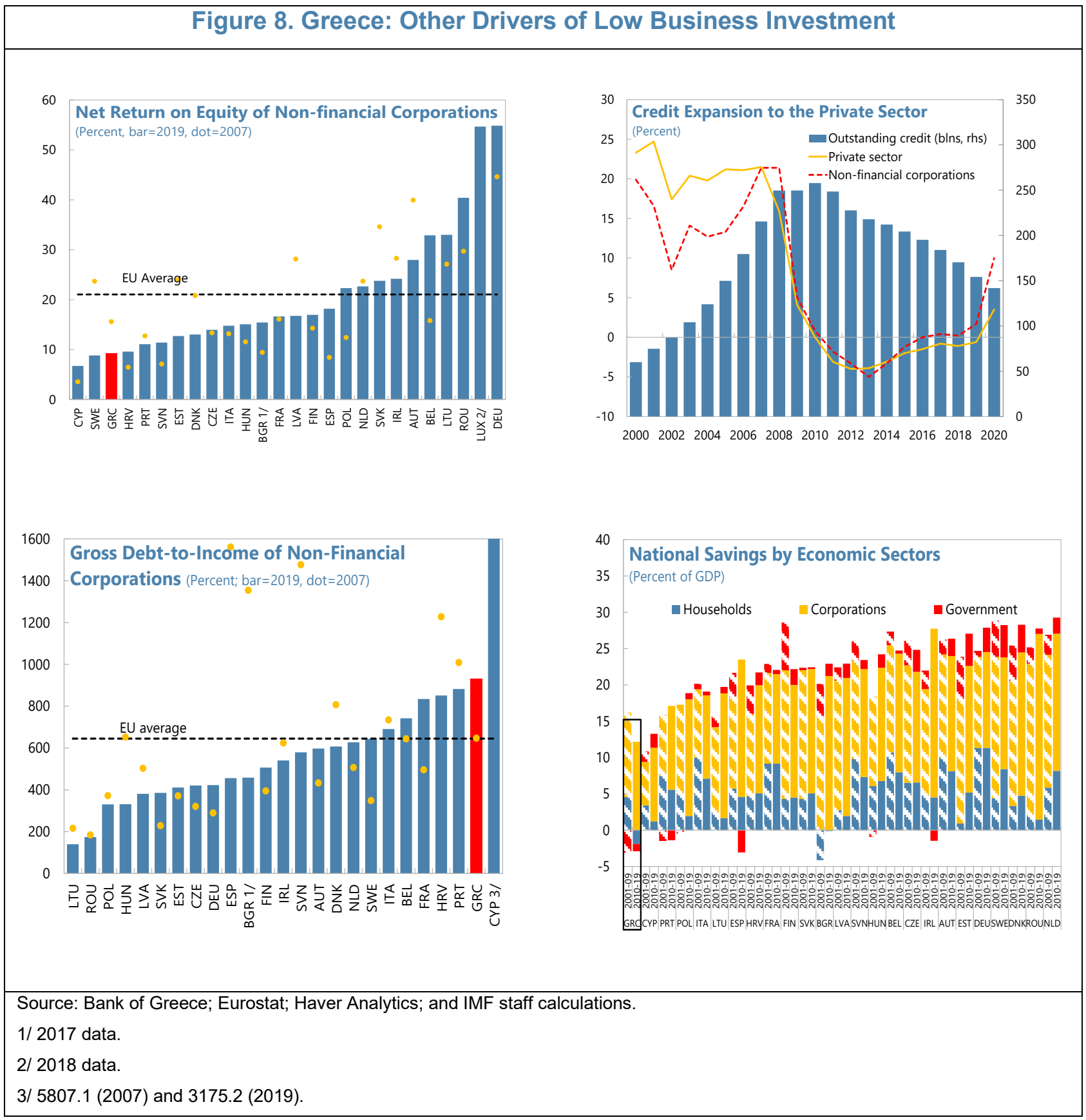




\section{Household investment seems to be closely linked to income and savings \\ dynamics (Figure 9). The household}

investment decline is in tandem with lower

household savings driven by the sharp decline in disposable income (text chart). Greece currently has the lowest saving rate among EU countries by a wide margin: average national saving from 2010 to 2019 was 9.2 percent of GDP, 13 percentage points below the regional average. While the public sector was historically

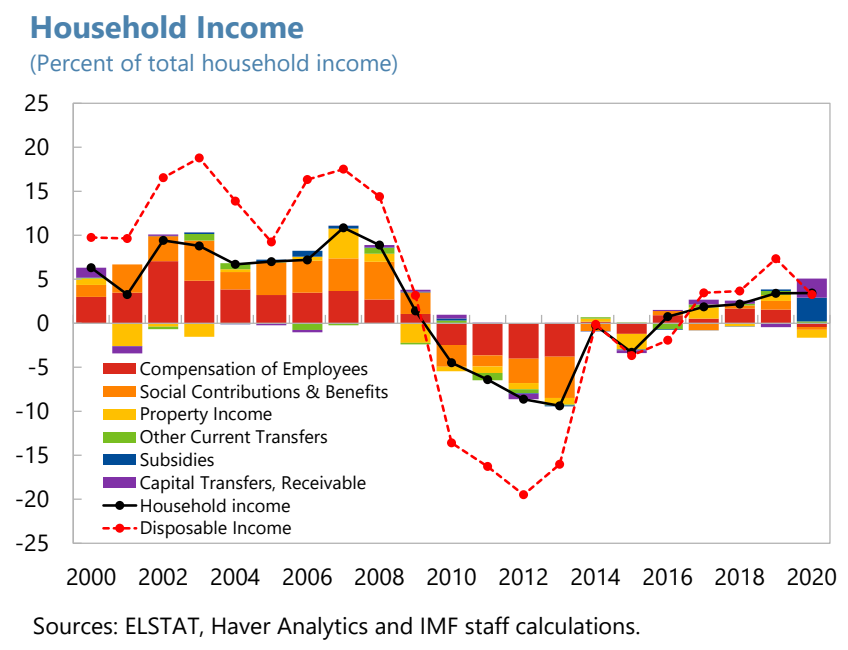

Sources: ELSTAT, Haver Analytics and IMF staff calculations.

the main driver of the low savings rate in Greece, household savings entered and have stayed in negative territory since 2012 despite the recovery in disposable income and employment (though this was in large part led by low-paying, part-time, or seasonal jobs). Wealth effects might also have been at play. While debt to income ratios seem to be broadly on par with the regional average, Greece's high degree of home ownership and investment through real estate, linked to plummeting housing prices after the sovereign debt crisis, have also driven the drop in investment, as Greek households are dis-saving to cope with the reduction in their disposable income and with the reduction in credit that used to finance housing expenditures. The real estate sector started to recover prior to the pandemic (partly driven by tourism and Airbnb) and real estate agents point to high interest in the sector due to the Golden Visa program (even through the pandemic) but transaction volume is difficult to ascertain as the statistics agency halted the production of series on housing starts or transactions after the GFC. Housing prices, however, continued increasing during the pandemic and through Q22021.

Public investment seems to have been broadly stable despite limited fiscal space. The public investment-to-GDP ratio has been stable and slightly higher than the regional average. This could be due to measurement issues (transfers classified as investment), the rising importance of EU structural funds in a shrinking economy, and/or necessary investments needed to maintain the relatively large public capital stock held by State-Owned Enterprises. As mentioned above, Greece's public-to-private capital ratio stands above the regional average at 45 percent at end-2019. 
Figure 9. Greece: Drivers of Household Investment
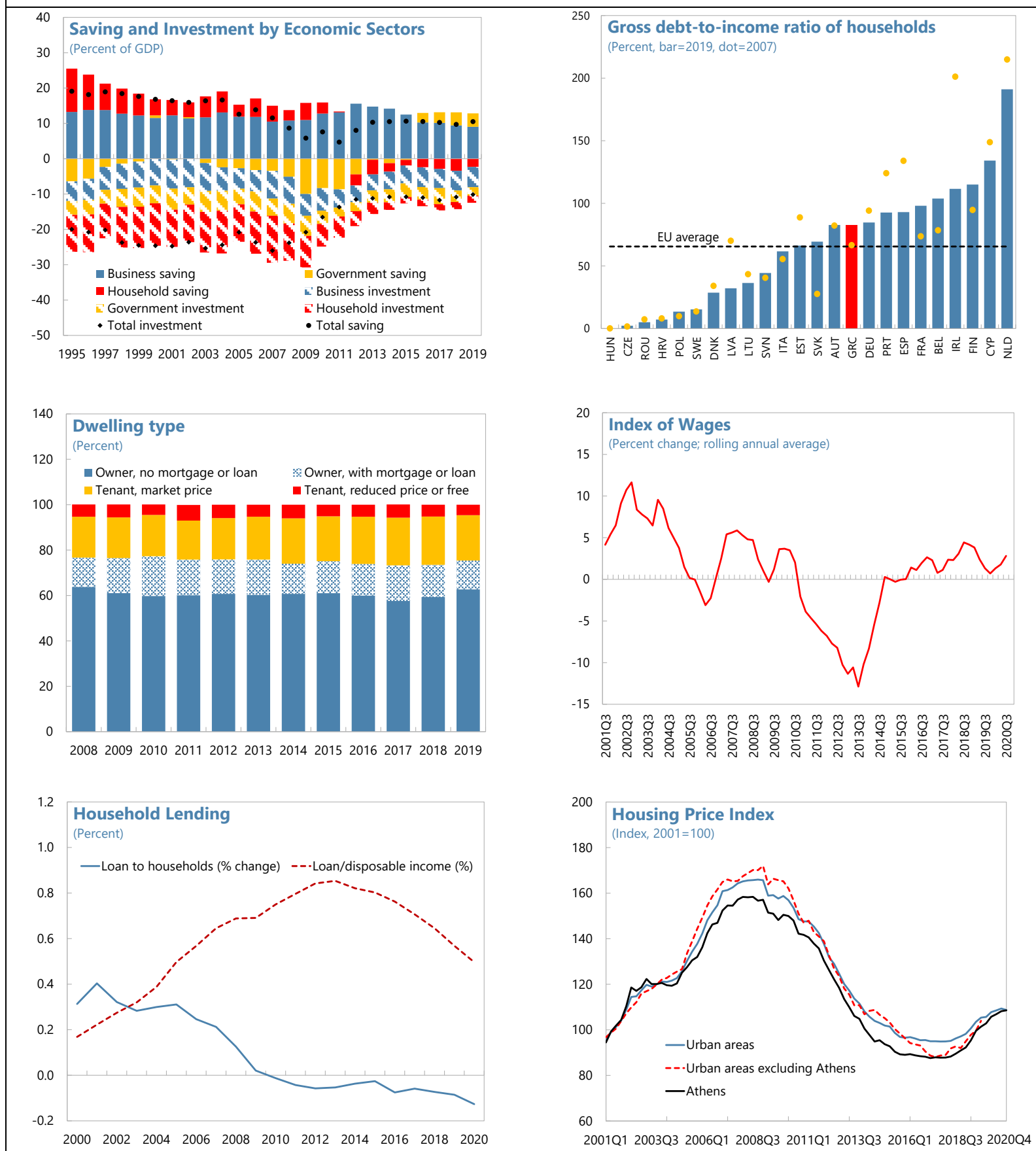

Source: Bank of Greece; ELSTAT; Eurostat; Haver Analytics; and IMF staff calculations. 


\section{E. Conclusion and Policy Recommendations}

There is scope for expanding the frontier of private investment possibilities in Greece through structural reforms and sound macro-financial policies. The "predicted norm" approach provides a useful investment benchmark based on cross-country evidence and Greece's own specific characteristics, while the equilibrium investment rate is estimated through the "golden-rule" approach. The two approaches complement each other, and together with the "historical benchmark", provide a good gauge of the magnitude of the investment gap. Consistent with the literature, two of the three approaches suggest Greece's low level of total investment is linked to structural features in the economy. The empirical analysis, in particular, finds that countries tend to invest more if they have a lower debt burden, a smaller service share (as these tend to be less capital-intensive), higher capital account openness, and better regulatory quality. The high degree of self-employment also seems to be holding back investment, though this by itself is not necessarily a concern. Rather, this could be linked to the prevalence of Greek micro firms that are constrained in their investment due to the size of the markets they serve or because of financing/technology constrains. Addressing these challenges, via product market reforms that encourage economies of scale and/or trade facilitation that integrates them into global markets could boost Greece's corporate investment and growth prospects. In turn, higher, more productive, private sector investment would improve earnings for employees and encourage savings. Thus, household investment could be expected to increase as disposable income grows, in line with higher wages and a more dynamic real estate market. Young people, in particular, tend to drive demand for housing but need access to credit, good-paying jobs, and availability of infrastructure and services (transport, childcare, elder care, and unemployment benefits) to feel secure enough to invest in a home.

The authorities are taking steps to tackle structural barriers. The authorities' Recovery and Resilience Plan (underpinned by the 2020 National Growth Strategy) features reforms focused on improving the investment climate (see also 2021 AIV Staff Report Box 2), geared towards modernizing the judicial system, digitalization, green investments, up- and re-skilling the labor force, and encouraging economies of scale. Other adopted policies that will support investment in the near term include a lower tax wedge and cuts to red tape in business processes. Other efforts by the authorities to improve public investment efficiency (interoperability of the public investment budget, establishment of a Strategic Projects Pipeline and a Project Preparation Facility) and NGEU-grant financed investment, if fully executed, should also boost the growth impact of public investment. Plans for several public-private partnerships, announced in the context of the NGEU, and implementation of the Government's Project Preparation Facility could also boost public investment growth that encourages private sector activity in the near term. To ensure the growth-friendliness of projects, the authorities also requested Public Investment Management Assessment (PIMA) technical 
assistance from the IMF. PIMA is currently in progress (albeit with some delays) and could help maximize the public investment payoffs of NGEU funds.

\section{More ambitious reforms could potentially unlock higher private investment without} endangering external sustainability. Some examples include overhauling the burdensome judicial system, finally completing the delayed cadaster reform, adjusting pensions to encourage private savings and labor force participation in older cohorts, and tackling on-the-ground barriers to more competitive product markets and closed professions, as recommended by the Hellenic Competition Commission. The cadaster reform and better insolvency practices introduced by the recent major reform of the Greek insolvency framework, in particular, could energize the long-dormant real estate sector. Completing long-promised privatization in key public infrastructure could also unlock higher, more sustainable investment rates, as long as it attracts greenfield projects that strengthen corporate governance and competition.

\section{Adequate sequencing of reforms and prioritization of public investment would} maximize the investment potential of NGEU resources in the near term. Prioritizing reforms that encourage structural transformation and keep growth momentum would help address private investment barriers. On the analytical front, exploring the interaction of public and private capital in Greece could help determine if supplementary or substitution effects dominate. This could help policymakers allocate public investment to areas that encourage and maximize productive private sector investment. 


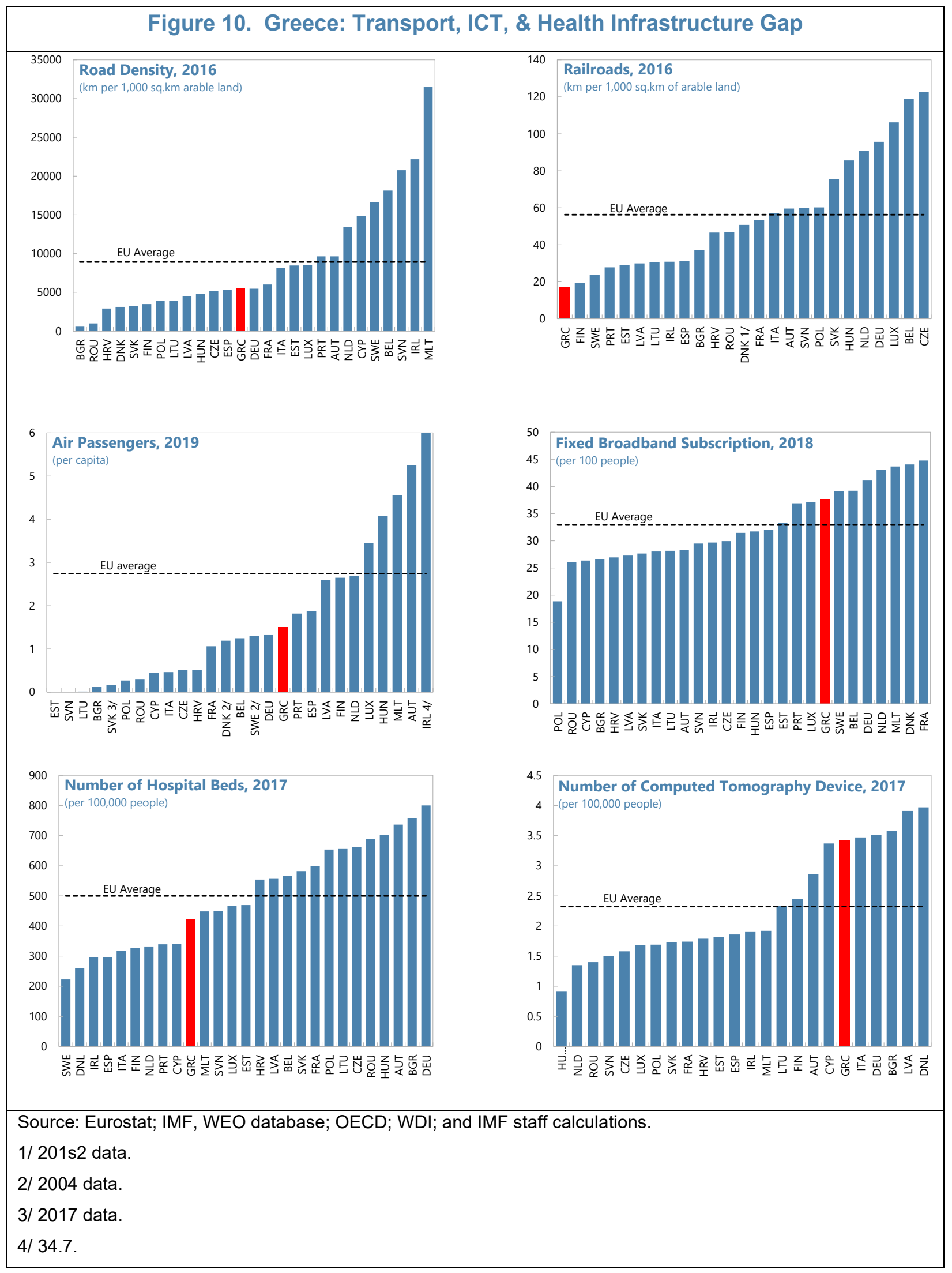




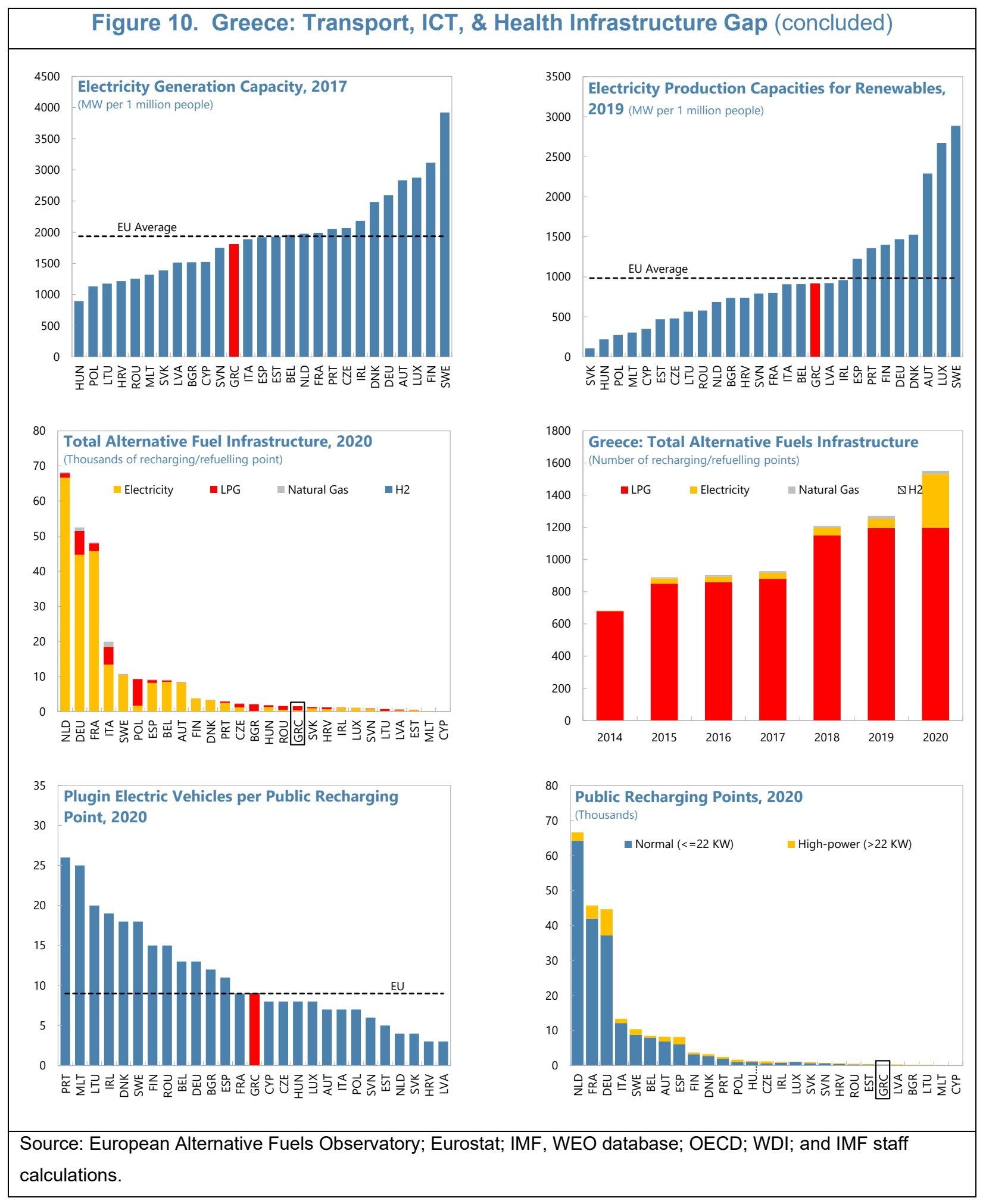

CInternational Monetary Fund. Not for Redistribution 


\section{Appendix I. Investment Gap Estimations ${ }^{9}$}

The Golden Rule approach can be interpreted as a lower bound to which a country's investment rate eventually converges as it approaches it's the steady state level, underpinned by its structural characteristics and exogenous parameters. A neo-classical growth model, modified to allow for exogenous growth of labor-augmenting productivity (Cass-Koopmans model) predicts that-for given parameters of the aggregate production function, social rate of time preference (SRTP), depreciation, exogenous growth rates of the labor force and labor-augmenting productivity, and initial conditions with positive values-an economy converges to a steady-state equilibrium, in which income, consumption, and capital all grow at a fixed rate equal to the sum of the growth rates of labor force and labor-augmenting productivity. In the augmented neoclassical (Ramsey-Cass-Koopmans) growth model, an economy converges to its steady state equilibrium where consumption is maximized, the saving/investment rate is constant at its "golden-rule" value, and income, consumption, and capital all grow at a fixed rate equal to the sum of the exogenous growth rates of the labor force and laboraugmenting productivity.

The "golden-rule" of capital accumulation is thus given by:

$$
\frac{S}{Y}=\frac{I}{Y}=\frac{\alpha(\delta+n+g)}{(p+\delta+n+g)}
$$

where $\alpha$ is the capital share of output; $p$ is the social rate of time preference; $\delta$ is the depreciation rate; $\mathrm{n}$ is the growth of the labor force; and $\mathrm{g}$ is the rate of technical progress.

The estimate replicated for Greece follows the methodology IMF (2016) used for European Union (EU) countries, using Penn World Tables (PWT) data, now updated to version 10.0. Similar to IMF (2016), we adjust the capital share of output based on Eurostat balance sheet data, reducing it by either 100 or 63 percent of self-employed income given Greece's prevalence of micro firms and large segment of self-employed. In IMF (2016), the SRTP is constant and set equal to 5 percent for all countries, corresponding to the SRTP derived from the golden rule under the assumption that the euro area has been close to its steady-state path of development on average over 2002-14. We test other SRTPs given the observed dis-saving in Greece over the past decade (and potential for future developments that might encourage saving in the future). In addition, the new PWT 9.0 data set now includes total factor productivity based on absorption (instead of domestic demand, the so-called

\footnotetext{
${ }^{9}$ See more details in the IMF REI (May 2016) and IMF Poland Selected Issues (July 2017).
} 
"Welfare-relevant TFP") which aims to capture TFP based on prices and quantities as perceived by consumers, not firms (the results do not vary much). The scenarios are included in Table 3.

\section{Appendix Table 1. Golden Rule Variations}

\begin{tabular}{lcl}
\hline Scenario & $\begin{array}{c}\text { Gap } \\
\text { (\% of GDP) }\end{array}$ & \multicolumn{1}{c}{ Adjustment } \\
\hline GR5 & -0.8 & Self-employed income accrues 100 percent to labor. \\
GR4 & 1.9 & SRTP=6 (higher consumption). \\
GR3 & 3.1 & Self-employed income accrues 67 percent to labor. \\
GR1 & $\mathbf{3 . 8}$ & No adjustment to PWT values, SRTP=5. \\
GR6 & 5.5 & Adjusted for welfare-relevant TFP (based on absorption). \\
GR2 & 6.3 & SRTP=4.0 (lower consumption). \\
GR7 & 6.9 & SRTP=3.5 (lowest consumption). \\
\hline
\end{tabular}

The Historical Benchmark provides a yardstick investment rate (for a given $\mathrm{K} / \mathrm{L}$ ratio and technology) that is consistent with capital accumulation path of selected advanced European economies during 1951-2011 that proved to be sustainable. The main advantage of this approach is that it does not require any assumptions about the social rate of time preference and the position of the country on the saddle-path. The main disadvantage is that it assumes similarity in economic structures of selected countries and their advanced peers. The benchmark values can be calculated for each country and each point in time, given the TFP and population growth rates, as well as the country's capital-labor ratio. The purpose of the benchmark is to provide a proxy for a sustainable path of the investment rate during the transition to a steady state. Although neoclassical growth theory does not offer a closed-form solution for such transition dynamics, the "catch-up" is essentially driven by differences in real interest rates that affect intertemporal choices of consumption and savings (the Euler equation; see Barro and Sala-i-Martin 2003). When relative capital scarcity makes capital more productive, bearing a higher real interest rate, it stimulates saving and investment rates and leads to faster pace of capital accumulation. With a rising K/L ratio, the real return to capital declines and saving and investment rates gradually fall to their steady-state constant level. The further the economy is from its steady-state $\mathrm{K} / \mathrm{Y}$ ratio, the faster it will accumulate capital. Therefore, the transition path for the investment rate I/Y may be approximated by a function of the real return to capital (given by the marginal product of capital, using Cobb-Douglas production function, where $A$ is labor-augmenting productivity, $\mathrm{K}$ is capital, $\mathrm{L}$ is labor, and $\alpha$ is the capital share): 


$$
\begin{gathered}
\frac{I_{t}}{Y_{t}} \cong f(M P K)=\alpha\left(\frac{K_{t}}{A_{t} L_{t}}\right)^{\alpha-1} \\
\ln \left(\frac{I_{t}}{Y_{t}}\right)=c+\beta \ln \left(A_{t}\right)-(1-\alpha) \ln \left(\frac{K_{t}}{L_{t}}\right)+\varepsilon_{t}
\end{gathered}
$$

and where in the steady-state $c$ equals $\ln (a)$ and $\beta$ equals (1-a). This suggests that the approximation of the transition path is a plausible transition dynamic since it converges into the balanced growth path. In order to evaluate the parameters $c, \alpha$, and $\beta$, we use the method used in IMF (2016), which established the historical experiences of countries in Western Europe with their capital accumulation path over 1951-2011. Fitting the above specified transition path for the investment rate on a panel for Germany, France, Italy, and Spain over 1951-2011 (R2=0.87, asterisks denote statistical significance with ${ }^{* *}$ at 1 percent and ${ }^{* *}$ at 5 percent), yielded:

$$
\ln \left(\frac{I_{t}}{Y_{t}}\right)=-0.18^{* *}+0.7^{* * *} \ln \left(A_{t}\right)-0.6^{* * *} \ln \left(\frac{K_{t}}{L_{t}}\right)
$$

Using these parameters and Greece's country-specific K/L ratio and labor-augmenting productivity, we computed the sustainable "historical benchmark" investment rate which mimics earlier transition dynamics of advanced economies. This approach may not be suitable for Greece under its current economic structure, as the period of time where the investment rate more closely approached the historical benchmark was characterized by unsustainable external and fiscal positions.

The "Predicted Norm" is estimated using a panel fixed-effects regression model for 27 EU countries (the actual sample size varies depending on data availability of different controlling variables) over the past three decades (see Appendix Table 2). The estimates shown in Text table 2 are based on the specification that includes both country and year fixed effects, as well as countries' economic fundamentals and structural characteristics identified in the literature as significant determinants of investment. The regression results are robust and broadly in line with expectations. In the simple fixed-effects specification, the country fixed effects capture all the unobservable (time-invariant) factors, including some slow-moving structural characteristics. However, based on the literature, surveys and stylized facts, there are some structural factors that seem to play an important role in explaining private investment activity in most countries. Hence, the regression specifications explicitly control for these factors, including regulatory efficiency, service share and financial account openness. Staff tested different control variables for Greece's structural characteristics, including the OECD's Product Market Regulation indicators, World Economic Forum Global Competitiveness Index and others. Alternative controls of economic fundamental were also considered, such as the NPL ratio and the export share of GDP. While we already included the time dummy to capture the evolvement of external conditions, we also tested other external factors, including the terms of trade 
and the uncertainty index, which were insignificant. Since most of the regressors are macro variables that might interact with each other, possible multicollinearity among regressors is detected, but it doesn't affect the overall fit and predictive power of our model. To further mitigate the impact of multicollinearity, we used different lagged values for key control variables, including GDP per capita and regulatory quality. Staff also ran additional robustness checks by using random effect models and dynamic panel models. Overall, the key results are robust in specifications with alternative control variables. The final, most complete model specification is a function of data availability and provides the best fit.

\begin{tabular}{|c|c|c|c|c|c|}
\hline \multicolumn{6}{|c|}{ Appendix Table 2. Predicted Norms: List of Variables } \\
\hline Variables & Description & Unit & Country & Time Series & Sources \\
\hline Investment rate & $\begin{array}{l}\text { Gross fixed capital } \\
\text { formation }\end{array}$ & $\begin{array}{l}\text { percent of } \\
\text { GDP }\end{array}$ & $\begin{array}{l}\text { EU27 } \\
\text { countries }\end{array}$ & $\begin{array}{l}\text { 1960-2019 or } \\
\text { longest } \\
\text { available }\end{array}$ & IMF WEO \\
\hline GDP per capita & GDP in constant prices, PPP & $\begin{array}{l}\text { International } \\
\$\end{array}$ & $\begin{array}{l}\text { EU27 } \\
\text { countries }\end{array}$ & $\begin{array}{l}\text { 1960-2019 or } \\
\text { longest } \\
\text { available }\end{array}$ & IMF WEO \\
\hline GDP growth & $\begin{array}{l}\text { Year-on-year GDP growth } \\
\text { rate }\end{array}$ & percent & $\begin{array}{l}\text { EU27 } \\
\text { countries }\end{array}$ & $\begin{array}{l}\text { 1960-2019 or } \\
\text { longest } \\
\text { available }\end{array}$ & IMF WEO \\
\hline $\begin{array}{l}\text { Private credit/GDP } \\
\text { growth }\end{array}$ & $\begin{array}{l}\text { Year-on-year change in } \\
\text { domestic credit to private } \\
\text { sector }\end{array}$ & $\begin{array}{l}\text { percent of } \\
\text { GDP }\end{array}$ & $\begin{array}{l}\text { EU27 } \\
\text { countries }\end{array}$ & $\begin{array}{l}\text { 1960-2019 or } \\
\text { longest } \\
\text { available }\end{array}$ & WB WDI \\
\hline $\begin{array}{l}\text { Short-term deposit } \\
\text { rate }\end{array}$ & Short-term deposit rate & percent & $\begin{array}{l}\text { EU22 } \\
\text { countries }\end{array}$ & $\begin{array}{l}\text { 1960-2019 or } \\
\text { longest } \\
\text { available }\end{array}$ & IMF WEO \\
\hline Debt/GDP & $\begin{array}{l}\text { The sum of general } \\
\text { government and private } \\
\text { sector debt }\end{array}$ & $\begin{array}{l}\text { percent of } \\
\text { GDP }\end{array}$ & $\begin{array}{l}\text { EU27 } \\
\text { countries }\end{array}$ & $\begin{array}{l}\text { 1995-2019 or } \\
\text { longest } \\
\text { available }\end{array}$ & $\begin{array}{l}\text { IMF WEO; } \\
\text { Eurostat }\end{array}$ \\
\hline $\begin{array}{l}\text { Service/Gross value } \\
\text { added }\end{array}$ & $\begin{array}{l}\text { The share of service sector } \\
\text { in gross value added }\end{array}$ & percent & $\begin{array}{l}\text { EU27 } \\
\text { countries }\end{array}$ & $\begin{array}{l}\text { 1995-2019 or } \\
\text { longest } \\
\text { available }\end{array}$ & Eurostat \\
\hline $\begin{array}{l}\text { Capital account } \\
\text { openness }\end{array}$ & $\begin{array}{l}\text { Lack of financial restrictions } \\
\text { on Capital account } \\
\text { transactions }\end{array}$ & Index, 0-100 & $\begin{array}{l}\text { EU26 } \\
\text { countries }\end{array}$ & $\begin{array}{l}\text { 1980-2018 or } \\
\text { longest } \\
\text { available }\end{array}$ & $\begin{array}{l}\text { Update on } \\
\text { Quinn and } \\
\text { Toyoda } \\
\text { (2008) }\end{array}$ \\
\hline Regulatory quality & World Bank estimates & Index, 0-3 & $\begin{array}{l}\text { EU27 } \\
\text { countries }\end{array}$ & $\begin{array}{l}\text { 1995-2019 or } \\
\text { longest } \\
\text { available }\end{array}$ & WB WGI \\
\hline
\end{tabular}




\section{References}

Bank of Greece, 2019, "Housing Wealth, Household Debt and Financial Assets: Are there Implications for Consumption?” BOG Working Paper No. 263 (Athens).

European Central Bank, 2016, "Savings and Investment Behavior in the Euro Area," ECB Occasional Paper Series No. 167.

European Commission, 2019, “2019 SBA Fact Sheet - Greece," (Brussels: European Commission).

European Investment Bank, 2019, "EIB Group Survey on Investment and Investment Finance 2019. Country Overview: Greece," European Investment Bank.

European Investment Bank, 2020, "EIB Group Survey on Investment and Investment Finance 2020. Country Overview: Greece," European Investment Bank.

Foundation for Economic and Industrial Research, 2019, "Boosting Savings and Growth through the Capital Markets," IOBE (Athens).

Feenstra, Robert C., Robert Inklaar and Marcel P. Timmer, 2015, "The Next Generation of the Penn World Table" American Economic Review, 105(10), 3150-3182, available for download at

https://www.ggdc.net/pwt

International Monetary Fund, 2016, Euro Area Policies, IMF Country Report No. 16/220 (Washington D.C.).

International Monetary Fund, 2016, "Central, Eastern, and Southeastern Europe: How to Get Back on the Fast Track” Regional Economic Issues (Washington).

International Monetary Fund, 2017, "Republic of Poland," IMF Country Report SM/17/178

(Washington)

International Monetary Fund, 2018, "Financial Conditions and Growth at Risk in Portugal," IMF Country Report No. 18/274 (Washington)

International Monetary Fund, 2019, "On Substitution of Private and Public Capital in Production," IMF WP/19/232 (Washington).

International Monetary Fund, 2020, "Infrastructure in Central, Eastern, and Southeastern Europe: Benchmarking, Macroeconomic Impact, and Policy Issues," (Washington). 
McKinsey Global Institute, 2012, "Investing in Growth: Europe's Next Challenge," (New York). National Bank of Greece, 2020, "Financial Frictions and Covid-19," NGB Economic Analysis Division, pp. 2-11.

Organization for Economic Co-operation and Development, 2001, "Measuring Capital" OECD Manual: Measurement of Capital Stocks, Consumption of Fixed Capital and Capital Services, OECD Publishing, Paris, 9-119.

PricewaterhouseCoopers, 2017, “From Recession to Anemic Recovery," PwC (Athens).

PricewaterhouseCoopers, 2020, "Infrastructure in Greece: Funding the Future," PwC (Athens).

ResearchGate, 1998, The White Paper on Growth, Competitiveness and Employment and Greek Small and Medium Sized Enterprises," Kluwer Academic Publishers.

World Economic Forum, 2019, “The Global Competitiveness Report 2019,” WEF (Geneva). 